\title{
Dried seahorse in traditional medicine: A narrative review
}

\author{
Siukan Law \\ Department of Science, School of Science and Technology, Hong Kong Metropolitan University, Ho Man \\ Tin, Kowloon, Hong Kong
}

\begin{abstract}
Seahorses are classified as members of Syngnathidae family, which includes pipefishes, pipehorses, and seadragons. China, including Hong Kong, uses 250 tons of seahorses as Traditional Chinese Medicine (TCM) every year. It is popular in Traditional Medicines (TM) especially TMC and its derivatives. The TCM formulations of dried seahorse strengthens the kidney and enhances immunity to treat the aging process. Base on the molecular biology analysis, $S 6$ ribosomal protein gene, $S 7$ ribosomal protein gene, and the $S 20$ ribosomal protein gene have been identified in dried seahorses, which help to reduce the cough symptoms. The present mini-review discusses the background of the use of dried seahorses, the TCM theory, the TCM formulations, the molecular biology, and analysis of its usage in traditional medicine.
\end{abstract}

\section{Introduction}

Seahorses belong to the family of Syngnathidae, which includes pipefishes, pipehorses, and seadragons. It counts more than 55 species. The genus name is Hippocampus. The size of sea-

Correspondence: Siukan Law, Department of Science, School of Science and Technology, Hong Kong Metropolitan University, Ho Man Tin, Kowloon, Hong Kong.

E-mail: siukanlaw@hotmail.com

Key words: Seahorse; Traditional Chinese Medicine.

Acknowledgments: Thanks to Prof. Kingming Chan for my MSc support.

Conflict of interest: The author has no conflict of interest to declare.

Availability of data and materials: All data generated or analyzed during this study are included in this published article.

Ethics approval and consent to participate: Not applicable.

Informed consent: Not applicable.

Received for publication: 6 August 2021.

Accepted for publication: 5 September 2021.

This work is licensed under a Creative Commons Attribution NonCommercial 4.0 License (CC BY-NC 4.0).

(C) Copyright: the Author(s), 2021

Licensee PAGEPress, Italy

Infectious Diseases and Herbal Medicine 2021; 2:158

doi:10.4081/idhm.2021.158 horses ranges between a few centimeters to 30 centimeters, and they live in shallow waters from temperate to tropical climate regions around the world. ${ }^{1}$ Seahorse's habitat includes coral reefs, mangroves, and seagrass meadows. They are monogamous, with low fertility and reproductive rate, also require a long period of parental care, and fragmented distributions enhance the vulnerability of these creatures. ${ }^{2}$

There are five seahorse species recorded in Hong Kong, namely Hippocamus kuda, Hippocampus trimaculatus, Hippocampus histrix, Hippocampus kelloggi, and Hippocampus spinosissimus. ${ }^{3}$ About 250 tons of these seahorse's species traded are used in traditional Chinese medicine per year to treat some aging and cough symptoms.

\section{Methods}

Some library search engines were used such as SCI/SCIE, PubMed, and Scopus. The keywords searched including "seahorse", "traditional Chinese medicine + seahorse", "molecular biology + seahorse" etc within twenty years, from 1999-2020.

\section{Traditional Chinese medicine theory}

Seahorses belongs to the category of tonics. It is classified as sweet, salty, and warm according to the TCM theory. $Q i$ is the internal energy that promotes better health to balance yin-yang for the whole body. If qi deficiencies, a person may take food remedies such as seahorse to restore the $q i$ because it is high in yang content. ${ }^{4}$

Seahorse functions to tone the kidneys, fortify yang, and invigorate the blood which enters the kidney and liver channels. ${ }^{5}$ The general Chinese clinical indications of seahorse are soreness and weakness of the loin and knees, impotence, sterility, enuresis, abdominal mass, scrofula, goiter, and trauma. It has health benefits for humans such as heal of pregnant women's dystocia, strengthens kidney function, enhances immunity, and eliminates tumors. ${ }^{6,7}$

\section{TCM formulations of dried seahorse}

Based on the TCM theory, seahorse belongs to the constitution of yin deficiency and fire prosperity. It is not suitable for people who a deficiency of fire, red eyes, sore gums, and unpalatable external feelings. The Compendium of Materia Medica or Bencao Gangmu identified that the dried seahorse "is good at abortion, so it stimulates birth." Pregnant women should avoid eating the dried seahorse. There is also a list of the dried seahorse diet therapy (Table $1)^{8}$

\section{Molecular biology and analysis of dried seahorse}

Dried Seahorse as TCM has two major functions including strengthening kidneys and enhancing immunity. It increases the male sex hormone (androgen) response. This is related to the kidney kinase and inhibits the production of phosphodiesterase-4 reducing the cough symptom identified by the $S 6$ ribosomal protein gene, $S 7$ ribosomal protein gene, and the $S 20$ ribosomal protein gene present in the dried seahorse's phylogeny. 
S6 ribosomal protein gene is $2.7 \mathrm{~kb}$ in length and composed of five exons. It is the major substrate of protein kinases in eukaryotic ribosomes. The function of its $S 6$ r-protein is highly conserved in distant eukaryotes. ${ }^{9}$

$S 7$ ribosomal protein gene is a discontinuous protein-coding gene. It consists of exons and introns. Small nucleolar RNAs (snoRNAs) are localized in the introns of the $S 7 \mathrm{r}$-protein gene. The exon and intron arrangement in the $S 7$ r-protein gene is highly conserved in distant vertebrate species. ${ }^{10}$

S20 ribosomal protein gene is a component of the 40S subunit located in the cytoplasm. It consists of exons and introns. Small nucleolar RNA gene, U54 located in the second intron and conserved between eukaryotes, prokaryotes, and archaebacterial. ${ }^{11}$ Some designed primers such as S6, S7, and S20 ribosomal protein genes are used to investigate the medical value of dried seahorse (Table 2).

\section{Research progress of dried seahorse}

Growing evidence has confirmed the value attributed to dried seahorse in TCM. Chang et al. reported seahorse was a unique appearance and exhibited male pregnancy which was a useful component of TCM. This investigated 58 dried seahorse samples collected from 23 Chinese herbal medicine stores across Taiwan using molecular forensics. ${ }^{12}$ Koning et al. discovered the use of DNA analysis in the species identification of seahorses. Genetic tools had been used to descript some new species of seahorse and their applications. ${ }^{13}$ Zhang et al. identified a total of 3372 Expressed Sequence Tags (ESTs) consisting of 1911 unique genes (345 clusters and 1566 singletons) for the hippocampus. The occurrence of high prevalent C-type lectins in the hippocampus suggested that a lectin-complement pathway might exert a more dominant function in the innate immune system of teleost than a mammal. ${ }^{14}$ Wang et al. indicated sixty-four COI sequences of 662

Table 1. Dried seahorse diet therapy.

\begin{tabular}{|c|c|c|c|}
\hline Diets & Materials & Recipes & Functions \\
\hline $\begin{array}{l}\text { (1) } \\
\text { Seahorse and red dates } \\
\text { stewed lean meat } \\
\text { (海馬紅雬燉瘦肉) }\end{array}$ & $\begin{array}{l}\text { 6g of hippocampus, } 5 \text { red dates } \\
\text { (cored), } 250 \mathrm{~g} \text { of lean pork, } \\
3 \text { slices of ginger. }\end{array}$ & $\begin{array}{l}\text { Wash the lean pork meat and } \\
\text { cut into pieces, put it in } \\
\text { boiling water and casserole. } \\
\text { Transfer the washed seahorse, } \\
\text { red dates, and ginger, boil it on } \\
\text { high heat, simmer for } 1 \\
\text { to } 1.5 \text { hours on low heat. } \\
\text { Add salt and serve. }\end{array}$ & $\begin{array}{l}\text { The effect of nourishing liver and kidney, nourishing } \\
\text { blood essence. It is especially suitable for people who } \\
\text { have symptoms such as fatigue, knee pain, frequent } \\
\text { urination at night, or men's impotence, } \\
\text { coldness, dizziness, tinnitus, chills, low blood, lower } \\
\text { abdomen, and other symptoms in women after } \\
\text { childbirth. }\end{array}$ \\
\hline
\end{tabular}

\begin{tabular}{|c|c|c|c|}
\hline $\begin{array}{l}\text { (2) } \\
\text { Seahorse Walnut Lean Meat Soup } \\
\text { (海馬核桃瘦肉湯) }\end{array}$ & $\begin{array}{l}250 \mathrm{~g} \text { of lean pork, } 5-10 \mathrm{~g} \text { of } \\
\text { hippocampus, } 15 \text { to } 30 \mathrm{~g} \text { of walnuts, } \\
4 \text { red dates. }\end{array}$ & $\begin{array}{l}\text { Wash the lean pork meat, } \\
\text { and cut it into pieces for later usage. } \\
\text { Put all the ingredients in a casserole, } \\
\text { add appropriate amount of water, } \\
\text { boil on high heat, simmer for } 1 \\
\text { to } 1.5 \text { hours, seasoning, and serve. }\end{array}$ & $\begin{array}{l}\text { The effect of warming on the kidney and } \\
\text { strengthening yang. It is especially suitable } \\
\text { for people with yang deficiency physique } \\
\text { or elderly people who suffer from asthmatic } \\
\text { asthma accompanied by exercise, resulting } \\
\text { in aggravated asthma and fatigue, elderly } \\
\text { people with waist and knee pain, or people } \\
\text { with the low male libido. }\end{array}$ \\
\hline $\begin{array}{l}\text { (3) } \\
\text { Seahorse Black Chicken Soup } \\
\text { (海馬烏雞湯) }\end{array}$ & $\begin{array}{l}10 \mathrm{~g} \text { of hippocampus, } 30 \mathrm{~g} \text { of peanuts, } \\
5 \text { red dates, } 400 \mathrm{~g} \text { of black-bone } \\
\text { chicken, } 3 \text { pieces of ginger. }\end{array}$ & $\begin{array}{l}\text { Wash the lean pork meat and cut it into pieces. } \\
\text { Put it in a casserole, add the washed seahorse, } \\
\text { red dates, and ginger, boil it on high heat, } \\
\text { simmer for } 1 \text { to } 1.5 \text { hours on low heat. } \\
\text { Add salt and serve. }\end{array}$ & $\begin{array}{l}\text { The effects of invigorating on the liver and kidney, } \\
\text { replenishing essence and blood. It is especially } \\
\text { suitable for people who have symptoms such as } \\
\text { fatigue, knee pain, frequent urination at night, or } \\
\text { men's impotence, coldness, dizziness, tinnitus, chills, } \\
\text { low blood, lower abdomen, and other symptoms } \\
\text { in women after childbirth. }\end{array}$ \\
\hline $\begin{array}{l}\text { (4) } \\
\text { Seahorse Anti-Asthmatic Soup } \\
\text { (海馬平喘湯) }\end{array}$ & $\begin{array}{l}10 \mathrm{~g} \text { of hippocampus, } 5 \mathrm{~g} \text { of } \\
\text { angelica, } 10 \mathrm{~g} \text { of northern apricot, } \\
2 \mathrm{~g} \text { of tangerine peel. }\end{array}$ & $\begin{array}{l}\text { The hippocampus is minced and chopped. } \\
\text { Combine the casserole pot with angelica, } \\
\text { apricot, and tangerine peel. Add water, } \\
\text { boil it for } 20 \text { minutes, and take the } \\
\text { reserved concoction for later use. } \\
\text { Add } 500 \mathrm{~mL} \text { of water to the dregs of medicine, } \\
\text { boil it to a large boil, simmer for } 15 \text { to } 20 \text { min } \\
\text { at a small boil, remove the slag and leave } \\
\text { the juice. Gradually, fry the concoction } \\
\text { from the bottom of the pot, boil, } \\
\text { and pour thoroughly. }\end{array}$ & $\begin{array}{l}\text { The effects of invigorating on the kidney and } q i \text {, } \\
\text { relieving cough, and relieving asthma. It is especially } \\
\text { suitable for people who have a cough, wheezing, and } \\
\text { wheezing worsened by movement, and people who } \\
\text { have less sputum. }\end{array}$ \\
\hline
\end{tabular}

Table 2. Forward (FWD) and reverse (REV) primer sequences for $S 6, S 20$, and $S 7$ ribosomal protein gene.

\begin{tabular}{ll} 
Name & Sequence \\
RPS6 & FWD 5'-ATAGAATACATGGCCCCTGAA-3' \\
REV & 5'-TGCTCCCAACTCCACCAAT-3' \\
RPS7 & FWD 5'-TGGCCTCTTCCTTGGCCGTC-3' \\
REV & 5'-AACTCGTCTGGCTTTTCGCC-3' \\
\hline RPS20 & FWD 5'-GAACAAGTCGGTCAGGAAGC-3' \\
REV & 5'-TTA[G/A]GCATCTGCATGGTGACTT-3' \\
\hline
\end{tabular}


bp length revealed 43 unique haplotypes. This DNA sequences analysis combined with morphological characteristics is conducive to accurately identify the zoological origin of commercial seahorses. ${ }^{15}$

\section{Discussion}

According to the Convention on International Trade in Endangered Species of Wild Fauna and Flora (CITES), seahorses are traded worldwide as TCM at least 20 million per year. China including Hong Kong has used 250 tons of seahorses as TCM every year. This saturation continuously increases within these several years because it is believed that seahorse has a medical value such as heal of pregnant women's dystocia, strengthen kidneys, enhance immunity, and eliminate tumors.

However, the species and number of seahorses decreases due to overharvesting. Seahorses become extinct since their life history is low reproductive rate, monogamy, sedentary behavior, and fragmented distributions. Some of the natural products from TCM have the same functions as a seahorse, e.g., Epimedium (仙靈脾), Ba-Wei Di-Huang Pills (八味地黃丸) including Rehmannia (熟地 黃), Rhizoma dioscoreae (淮山), Common macrocarpium fruit (山 英肉), Indian buead (白获苓), Cortex moutan (牡丹皮), Alisma orientale (澤瀉), Cinnamomum cassia presl (肉桂) and Radix aconiti praeparata (炮附子) are strengthening kidneys. Radix polygoni mul-tiflori (制何首烏), Radix glehniae (北沙参) and Radix salviae miltiorrhizae (紫丹参) are enhancing immunity.

\section{Conclusions}

The function of dried seahorse in TM is confirmed by molecular authentication. It strengthens the kidney and enhances immunity to treat some aging as well as cough symptoms. Some other natural products used in TCM have the same functions as a seahorse.

\section{References}

1. Lourie SA, Pritchard JC, Casey SP, et al. The taxonomy of Vietnam's exploited seahorses (family Syngnathidae). Biol J Linnean Soc 1999;66:231-56.

2. Foster SJ, Vincent ACJ. Life history and ecology of seahorses: implications for conservation and management. J Fish Biol 2004;65:1-61.

3. Lourie SA, Foster SJ, Cooper EWT, Vincent ACJ. A guide to the identification of seahorses. Project Seahorse and TRAFFIC North America. Washington D.C.: University of British Columbia and World Wildlife Fund, 2004.

4. Ried K, Stuart K. Efficacy of Traditional Chinese Herbal Medicine in the management of female infertility: A systematic review. Complement Ther Med 2011;19:319-31.

5. Bensky D, Clavey S, Stoger E. Chinese herbal medicine: Materia Medica, 3rd edition. Seattle: Eastland Press, 2004.

6. Meng XQ, Xu DH, Mei XT. Research on Hippocampus capsule therapy of experimental benign prostatic hyperplasia. Chin Pharm J 2005;40:190-3.

7. Zhang CH, Ni QG, Wu LY. Studied on antitumor activity of Trachyrhamphus serratus. China Marine Drugs 1998;4:10-2.

8. Aung SK, Fay H, Hobbs RF. Traditional Chinese Medicine as a Basis for Treating Psychiatric Disorders: A Review of Theory with Illustrative Cases. Med Acupunct 2013;25:398-406.

9. Gross T, Nischt R, Gatermann K, et al. Primary structure of the ribosomal protein gene S6 from Schizosaccharomyces pombe. Curr Genet 1988;13:57-63.

10. Cecconi F, Crosio C, Mariottini P, et al. A functional role for some Fugu introns larger than the typical short ones: the example of the gene coding for ribosomal protein S7 and snoRNA U17. Nucleic Acids Res 1996;24:3167.

11. Chan HY, Zhang Y, O'Kane CJ. Identification and characterization of the gene for Drosophila S20 ribosomal protein. Gene 1997;200:85-9.

12. Chang $\mathrm{CH}$, Liaw NHJ, Lin YS, et al. Authenticating the use of dried seahorses in the traditional Chinese medicine market in Taiwan using molecular forensics. J Food Drug Anal 2013;21:310-6.

13. Koning S, Hoeksema BW. Diversity of Seahorse species (Hippocampus spp.) in the International Aquarium Trade. Diversity 2021;13:187.

14. Zhang N, Xu B, Mou C, et al. Molecular profile of the unique species of traditional Chinese medicine, Chinese seahorse (Hippocampus kuda Bleeker). FEBS Lett 2003;550:124-34.

15. Wang X, Zhong H, Guo J, Hou F. Morphology and molecular identification of the zoological origin of medicinal seahorses in Chinese herbal markets. Mitochondrial DNA Part A 2020;31:335-45. 